\title{
TIPOLOGI KEPEMIMPINAN DALAM PENINGKATAN MUTU PENDIDIKAN ISLAM DI MADRASAH
}

\author{
${ }^{1}$ Fauzi Fahmi, ${ }^{2}$ Wahyu Iskandar \\ ${ }^{1}$ Universitas Islam Negeri Maulana Malik Ibrahim Malang \\ e-mail: Fauzifahmi1995@gmail.com \\ ${ }^{2}$ Universitas Islam Negeri Sunan Kalijaga Yogyakarta \\ e-mail:wiskandar921@gmail.com
}

\begin{abstract}
Stakeholder ideas and ideas in their reactualization never stop contributing discourse to change in the field of education. The leaders of educational institutions have full responsibility in carrying out improving the quality of education. This study aims to introduce leadership typologies in improving the quality of Islamic education in madrasas, ranging from the type of leadership, the leadership process of madrasa heads to the implementation of leadership in madrassas in improving quality. This research uses a literature study method. As for the results of this study indicate the role of leadership in carrying out its duties to members include: (a) Making decisions. (b) Developing the imagination; (c) Developing the loyalty of followers; (d) Control of the plan; (e) Utilizing human resources and other resources. ( $f$ ) Carry out controls and corrections for errors; $(g)$ Give a token of appreciation; ( $h$ ) Delegating authority to subordinates; (i) Implement decisions by giving encouragement to followers.
\end{abstract}

Keywords:Leadership, Quality, Islamic Education

\section{PENDAHULUAN}

Keberhasilan suatu lembaga atau organisasi terletak pada kepemimpinan. Kepemimpinan merupakan proses mempengaruhi dalam menentukan tujuan organisasi, mempengaruhi untuk perbaikan kelompok dan budayanya serta memotivasi perilaku anggota guna mencapai tujuan. ${ }^{1}$ Dengan adanya pemimpin mewujudkan sasaran yang akan dicapai.apabila sistem yang dilalukan berjalan dengan baik. Peran pemimpin dalam sebuah organisasi sangat penting karena kunci utama dalam sebuah organisasi atau lembaga ditujukan pada pemimpin.

Pemimpin sebagai sosok yang digugu dan ditiru, dalam Islam sosok panutan sebagai seorang pemimpin adalah Nabi Muhammad Saw. Dengan demikian manusia menjadikan sosok panutan sebagai contoh dalam dirinya guna diimplementasikan dalam kehidupan sehari-hari. Kata pemimpin dalam Islam identik dengan kata khalifah, manusia sebagai pemimpin atau khalifah di muka bumi. Sesuai dengan firman Allah Swt dalam surah Al-Baqarah ayat 30 yang berbunyi:

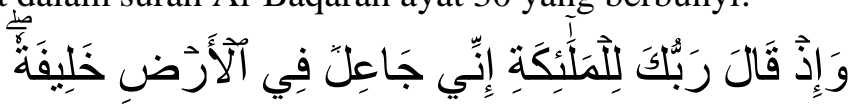

Artinya: "Ingatlah ketika Tuhanmu berfirman kepada para Malaikat: "Sesungguhnya Aku hendak menjadikan seorang khalifah di muka bumi".

${ }^{1}$ Mulyadi, Kepemimpinan Kepala Sekolah Mengembangkan Budaya Mutu, (Malang: UIN-Maliki Press, 2010), 1. 
Terjemahan ayat tersebut bahwa manusia sebagai khalifah yang akan memakmurkan bumi, sehingga tugas dan peran manusia sangat penting dalam mencapai tujuan kepemimpinan. Dengan demikian jika diterapkan dalam dunia pendidikan sebagai seorang pemimpin tugas dan kewajiban seorang pemimpin harus dilaksanakan dengan efektif guna mencapai keberhasilan dalam suatu lembaga dan organisasi.

Keberhasilan seorang pemimpin dalam mempengaruhi anggotanya untuk mencapai tujuan dalam suatu lembaga berdampak kepada mutu pendidikan itu sendiri. Mutu dalam Islam menurut Muhaimin dalam Mulyadi $^{2}$ diartikan sebagai perbuatan baik yang dilakukan kepada semua pihak dalam lingkup organisasi atau lembaga. Dengan demikian peran pemimpin sangat penting untuk mewujudkan pendidikan Islam yang bermutu. Oleh karena itu, guna mencapai mutu pendidikan Islam dalam lingkup organisasi dibutuhkan kerja tim yang baik dan setiap aktivitas yang dilakukan harus efektif dan efesien guna memperoleh hasil yang maksimal. Maka dalam hal ini, tulisan ini mendeskripsikan terkait apa saja jenis kepemimpinan dalam mutu pendidikan islam, bagaimana peran kepemimpinan mutu pendidikan Islam sampai kepada implementasi kepemimpinan mutu pendidikan Islam di Madrasah.

\section{METODE}

Penelitian ini menggunakan metode studi kepustakaan yang mengandalkan sumber bibliografi dari buku dan artikel di jurnal ilmiah yang berkaitan dengan pokok permasalahan, pembacaan data dengan pemikiran para ahli dengan pendekatan konstruktif dan interpretasi pada isi pokok.

\section{HASIL DAN PEMBAHASAN}

Menurut Mulyadi ${ }^{3}$ mengatakan bahwa kepemimpinan merupakan seni guna mempengaruhi aktivitas individu atau kelompok secara sengaja untuk mencapai tujuan lembaga atau organisasi. Selanjutnya Muhaimin ${ }^{4}$ menegaskan bahwa kepemimpinan adalah pemberian pengaruh kepada orang lain untuk melaksanakan suatu tujuan secara efektif dan efesien.

Sedangkan menurut Megan ${ }^{5}$ berasumsi bahwa kepemimpinan adalah tugas seseorang untuk mempengaruhi performa dari organisasi dengan mempengaruhi perilaku dan pikiran pengikutnya. Ditambahkan oleh Peter dalam Sallis ${ }^{6}$ menegaskan memberikan gambaran secara spesifik bahwa

\footnotetext{
${ }^{2}$ Mulyadi, Kepemimpinan Kepala Sekolah, 79.

${ }^{3}$ Mulyadi, Kepemimpinan Kepala Sekolah, 8.

${ }^{4}$ Muhaimin, Manajemen Pendidikan: Aplikasinya dalam Penyusunan Rencana Pengembangan Sekolah/Madrasah, (Jakarta: Kencana, 2011), 30.

${ }^{5}$ Megan Crawford, Leadership and teams in educational management, Terj. Erick Dibyo, (Jakarta: grasind, 2005), 18.

${ }^{6}$ Edward Sallis, Total Quality Management in Education, (Yogyakarta: IRCiSoD, 2012), 71.
} 
kepemimpinan merupakan seorang yang harus melakukan inovasi dan menciptakan rasa kekeluargaan kepada para staf, anggota bawahan untuk mencapai tujuan organisasi.

Dengan demikian dari beberapa ahli tersebut dapat disimpulkan bahwa kepemimpinan merupakan individu yang bertugas untuk mempengaruhi anggota atau kelompok dengan tujuan untuk mencipatakan keberhasilan dalam suatu organisasi atau lembaga.

Menurut Sallis ${ }^{7}$ mutu merupakan sebuah cara yang menentukan produk tersebut sesuai dengan standar atau belum. Sedangkan menurut Mulyadi $^{8}$ menegaskan bahwa mutu adalah kesesuaian dengan standar, harapan dan pemenuhan janji yang diberikan kepada pelanggan. Dengan demikian bahwa mutu merupakan hasil dari produk yang sesuai dengan harapan pelanggan atau konsumen.

Menurut Salminawati ${ }^{9}$ mengatakan bahwa pendidikan Islam merupakan pengajaran yang bersumber pada pendidikan dari Allah Swt sebagai sang pendidik seluruh ciptaan-Nya termasuk manusia. Sejalan dengan Syafaruddin ${ }^{10}$ mengatakan pendidikan Islam merupakan pembinaan manusia menjadi individu atau kelompok yang memiliki tanggung jawab setiap melakukan pekerjaan kepada manusia, alam dan Allah Swt.

Pada simpulannya bahwa kepemimpinan mutu pendidikan Islam merupakan individu yang bertugas untuk mempengaruhi anggota atau kelompok untuk mencipatakan keberhasilan.yang sesuai dengan harapan pelanggan pada lembaga pendidikan yang membina manusia pada tataran keberagamaan untuk memiliki potensi dan kepribadian yang Islami,

\section{Peran Kepemimpinan Mutu Pendidikan Islam}

Menurut Hasibuan dalam Mulyadi ${ }^{11}$ mengatakan bahwa perilaku kepemimpinan dalam melaksanakan tugas-tugas kepemimpinan meliputi aktivitas sebagai berikut:

a. Mengambil keputusan.

Peran seorang pemimpin sangat dibutuhkan dalam setiap aktivitas, dengan demikian bahwa pemimpin harus memliki ketegasan dalam mengambil keputusan, karena pekerjaan yang menentukan pada tahap akhir adalah seorang pemimpin.

b. Mengembangkan imajinasi;

Seorang pemimpin dituntut untuk memliki kelebihan dan keunggulan dari anggota atau bawahannya dalam merancang, mendesain dan mengembangkan inovasi baru untuk menciptakan hasil yang lebih baik,

c. Mengembangkan kesetiaan pengikutnya;

${ }^{7}$ Edward Sallis, Total Quality Management, 53.

${ }^{8}$ Mulyadi, Kepemimpinan Kepala Sekolah, 79.

${ }^{9}$ Salminawati, Filsafat Pendidikan Islam, (Bandung, Media Perintis, 2016), 108.

${ }^{10}$ Syafaruddin, Ilmu Pendidikan Islam, (Jakarta: Hijri Pustaka, 2014), 28.

${ }^{11}$ Mulyadi, Kepemimpinan Kepala Sekolah Mengembangkan Budaya Mutu, (Malang: UIN-Maliki Press, 2010), 47. 
Pemimpin yang efektif adalah seorang yang mampu membangun komunikasi dan kolaborasi baik dengan anggota untuk menciptakan hubungan yang erat dalam lingkup organisasi.

d. Pengendalian rencana;

Pada konteks ini organisasi adanya rencana yang dirancang sebagai upaya untuk berjalannya suatu program dalam lembaga, sehingga perlu adanya pengendalian yang dilakukan oleh pemimpin sebagai pengawasan setiap aktivitas.

e. Memanfaatkan sumber daya manusia dan sumber-sumber lainnya.

Sebagai makhluk sosial yang mampu membangun komunikasi efektif dengan sesame manusia, seorang pemimpin mampu memanfaatkan anggota atau bawahan dalam setiap kegiatan untuk mempermudah berjalannya setiap aktivitas.

f. Melaksanakan kontrol dan perbaikan-perbaikan atas kesalahan;

Pemimpin sebagai pengawasan, pengendali, pemeriksa setiap aktivitas anggota kelompoknya, maka seorang pemimpin harus mengontrol setiap hari pekerjaan yang dilakukan dan melakukan evaluasi untuk perbaikan setiap kesalahan sehingga akan memperoleh hasil yang maksimal.

g. Memberikan tanda penghargaan;

Pemimpin yang disenangi oleh bawahan atau anggota kelompok adalah pemimpin yang memiliki sikap peduli dan penuh dengan keakraban pada anggota kelompok. Cara yang dilakukan dengan memberikan reward atau hadiah pada anggota yang memiliki prestasi.

h. Mendelegasikan wewenang kepada bawahannya;

Pemimpin yang demokratis harus mampu memberikan pekerjaan dengan cara mengutus anggota atau bawahannya dalam setiap pertemuan di lembaga, seperti Pelatihan Profesi Guru dan sebagainya.

i. Pelaksanaan keputusan dengan memberikan dorongan kepada para pengikutnya.

Keputusan dalam setiap tindakan melibatkan anggota atau bawahan dengan dorongan untuk mencapai keberhasilan bersama setiap aktivitas yang dilakukan. Sedangkan menurut Kasali dalam Muhaimin $^{12}$ mengungkapkan bahwa adapun tingkatan dalam kepemimpinan dalam proses pelaksanaan kegiatan mempengaruhi anggota agar kepala sekolah/madrasah mampu memimpin dengan efektif meliputi empat unsur. Pertama, Visi (vision). Kedua, keberanian (cairageness). Ketiga, Realita (reality). Keempat, Etika (ethics).

Pertama, kepala sekolah/madrasah harus mampu memiliki visi yang baik dalam memimpin. Dengan adanya visi akan menciptakan semangat dalam lingkup lembaga dan adanya kerjasama atau kolaborasi antara pemimpin dengan bawahan guna mewujudkan suatu hasil yang akan dicapai.

\footnotetext{
${ }^{12}$ Muhaimin, Manajemen Pendidikan: Aplikasinya dalam Penyusunan Rencana Pengembangan Sekolah/Madrasah, (Jakarta: Kencana, 2011), 31-32.
} 
Kedua, seorang kepala sekolah/madrasah memiliki keberanian yang besar dalam menyikapi segala hal dan mengambil sebuah keputusan dengan bijaksana. Keberanian seorang pemimpin sangat dibutuhkan dalam lembaga atau sekolah karena dengan sikap tersebut seorang pemimpin layak sebagai sosok panutan dan idola bagi anggota untuk meningkatkan motivasi dalam bekerja.

Ketiga, pemimpin yang efektif merupakan pemimpin yang mampu bekerja secara konkret sesuai dengan realitas yang ada. Dalam hal bekerja sama dengan anggota atau bawahan seorang kepala sekolah/madrasah mampu membuktikan dirinya sebagai panutan. Hasil yang didapat saat ini harus dipaparkan sesuai kenyataan. Dengan demikian ketika akan mendapatkan program secara berkelanjutan maka adanya perbaikan-perbaikan secara terus menerus.

Keempat, kepala sekolah/madrasah sebagai sosok panutan yang harus digugu dan ditiru, sehingga sebagai seorang pemimpin mampu mencerminkan etika dan akhlak yang luhur sesuai dengan ajaran Islam kepada para guru dan stafnya. Sebagai suri tauladan yang baik seorang pemimpin wajib mencontoh pribadi Rasulullah Saw sebagai panutan bagi seluruh umat. Dengan demikian bahwa adanya etika dalam lingkup organisasi mewujudkan hubungan erat antar sesame pemimpin dengan angggota maupun anggota dengan anggota.

Selain itu, adapun prinsip yang harus dimiliki seorang pemimpin yang dijelaskan para ulama muslim merupakan penjabaran sifat Rasulullah Saw sebagai sumber teladan kepemimpinan Islami. Sifat dan perilaku Rasulullah merupakan cerminan dari Al-Qur'an yang beliau ajarkan kepada para sahabat dan samapai kepada umatnya hingga saat ini.

Sifat kepemimpinan yang dijelaskan di dalam Al-Qur'an meliputi: (1) amanah yang memiliki sifat kejujuran dan dapat dipercaya, (2) adil sebagai sifat yang harus dimiliki seorang pemimpin yang tidak membeda-bedakan antar sesama. (3) musyawarah dengan menerima pendapat anggota atau bawahan dan tidak otoriter. (4) Amr ma'ruf nahi mungkar dengan melakukan perbuatan yang baik dan mendekatkan diri kepada Allah Swt. ${ }^{13}$

Ditambahkan oleh Sallis ${ }^{14}$ bahwa fungsi pemimpin sebagai berikut: (a) Memiliki visi mutu terpadu bagi institusi. (b) Memiliki komitmen yang jelas dalam meningkatkan mutu. (c) Mengkomunikasikan pesan mutu. (d) Memastikan kebutuhan pelanggan. (e) Mengarahkan perkembangan karyawan. (f) Berhati-hati dengan tidak menyalahkan orang lain. (g) Memimpin inovasi dalam institusi. (h) Mampu memastikan struktur organisasi secara jelas. (i) Membangun tim yang efektif. (j) Mengawasi dan mengevaluasi segala aspek untuk kesuksesan.

\section{Implementasi Kepemimpinan Mutu Pendidikan Islam di Madrasah}

Kepemimpinan sebagai upaya mempengaruhi orang lain untuk melakukan aktivitas guna mencapai tujuan bersama. Kepemimpinan memiliki peran yang strategis dalam menentukan maju

${ }^{13}$ Aldo Syam, Konsep Kepemimpinan Bermutu dalam Pendidikan Islam, At-Ta'dib. Vol. 12. No. 2, (December 2017), 57-62.

${ }^{14}$ Edward Sallis, Total Quality Management in Education, (Yogyakarta: IRCiSoD, 2012), 173-174. 
tidaknya suatu organisasi. Sebagai pimpinan tertinggi yang memiliki tugas dan peran yang sangat penting dalam mewujudukan keberhasilan sekolah/madrasah. ${ }^{15}$ Pada akhirnya seorang pemimpin akan memperoleh kewenangan dalam mengimplementasikan dalam pendidikan dengan baik. Agar mampu memimpin dengan baik, maka pemimpin harus mencitai orang-orang yang dipimpinnya. Dalam sebuah hadis Nabi Muhammad Saw bersabda:

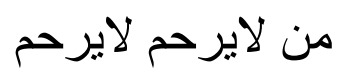

"Siapa saja yang tidak mencintai (tidak mengasihi) orang lain, maka ia tidak akan dicintai (dikasih sayangi) orang lain”.

Pemimpin sebagai orang yang berperan penting dalam lingkup manajemen sekolah. Adapun tipe seorang pemimpin menurut Mulyadi ${ }^{16}$ dapat dikelompokkan dan memiliki cirri-ciri tersendiri sebagai berikut:

a. Pemimpin Otoriter

Pada tipe ini seorang pemimpin memiliki peran sebagai orang yang mempunyai tanggung jawab penuh terhadap organisasi. Sukses tidaknya sebuah lembaga atau organisasi terletak pada dirinya sebagai pemimpin. Pemimpin yang berkerja secara sungguh-sungguh, bekerja keras, tertib dan tidak boleh dibantah. Sikapnya senantiasa mau menang sendiri, tidak mau menerima pendapat dari bawahan.

Pemimpin Otoriter memiliki ciri antara lain: (1) Beban kerja organisasi pada umunya ditanggung oleh pimpinan; (2) Konsep atau ide ide baru berasal dari pimpinan, dan bawahan sebagai pelaksana; (3) Disiplin tinggi, berkerja keras, dan tidak kenal lelah, (4) Kebijakan ditentukan oleh pemimpin sendiri dan kalau ada musyawarah sifatnya pemberitahuan/sosialisasi; (5) Kepercayaan pimpinan terhadap bawahan rendah; (6) Komunikasi dilakukan satu arah dan tertutup; dan (7) Korektif dan minta penyelesaian tugas tepat waktu.

b. Pemimpin Demokratis

Pada tipe ini pemimpin melibatkan anggota atau bawahan sebagai kolaborasi ide untuk menciptakan tujuan organisasi. Adanya keterbukaan dan keinginan dalam berpendapat setiap pekerjaan secara bersama-sama untuk mencapai tujuan yang bermutu. Danin dalam Mulyadi mengatakan bahwa kepemimpinan demokratis adalah kepemimpinan yang dilandasi oleh karena interaksi kelompok yang dinamis akan mewujudkan tujuan organisasi yang akan dicapai.

Adapun ciri kepemimpan demokratis antara lain: (1) Beban kerja organisasi menjadi tanggung jawab bersama seluruh personal organisasi: (2) Bawahan, oleh pimpinan

\footnotetext{
${ }^{15}$ Hasan Baharun, "Peningkatan kompetensi guru melalui sistem kepemimpinan kepala madrasah," AtTajdid: Jurnal Ilmu Tarbiyah 6, no. 1 (2018): 2.

${ }^{16}$ Mulyadi, Kepemimpinan Kepala Sekolah . 45-47.
} 
dianggap sebagai komponen pelaksana dan secara integral harus diberi tugas dan tanggung jawab; (3) Disiplin, tetapi tidak kaku dan memecahkan masalah secara teratur; (4) Kepercayaan tinggi terhadap bawahan dengan tidak melepaskan tanggung jawab pengawasan; dan (5) Komunikasi dengan bawahan bersifat terbuka dan dua arah..

c. Pimpinan Permisif

Pemimpin yanh memiliki tipe permisif bermakna serba boleh, mengiyakan tidak mau ambil pusing, tidak bersikap dalam makna sikap sesungguhnya dan apatis. Pemimpin permisif tidak mempunyai pendirian yang kuat, sikapnya serba boleh. Bawahan tidak mempunyai pegangan yang jelas, informasi diterima simpang siur dan tidak konsisten. Ciri pimpinan yang permisif antara lain: (1) Bawahan tidak mempunyai pegangan yang jelas dan kepercayaan rendah pada diri sendiri; (2) Menerima semua saran; (3) Pimpinan lamban dalam membuat keputusan; dan (4) Ramah dan banyak "mengambil muka" kepada bawahan.

Kepemimpinan pada pendidikan Islam merupakan sistem yang terpadu, yang memberikan keseimbangan antara tugas dan tanggungjawab pemimpin dan anggota. Keseimbangan ini mengindikasikan bahwa sistem Islami selalu menempatkan diri pada posisi tengah-tengah dalam kewenangan yang ada. Kepemimpinan Islami tidak mengorbankan kepentingan kelompok dalam kepemimpinan otoriter, dan juga sebaliknyam tidak mengorbankan pemimpin sebagaimana kepemimpinan laissez faire. ${ }^{17}$

Kepala madrasah merupakan manajer terdepan dalam sistem pendidikan yang mengatur berjalannya proses kegiatan pembelajaran. ${ }^{18} \mathrm{Pada}$ suatu lembaga sekolah/madrasah kepala sekolah/madrasah merupakan pemimpin sebagai kunci pendorong bagi kemajuan dan perkembangan sekolah serta bertanggungjawab untuk meningkatkan kualitas keberhasilan peserta didik dan program yang dijalankan. Untuk mencapai program tersebut maka kepala sekolah perlu diberdayakan, sehingga kepala sekolah mampu berperan sesuai dengan tanggungjawab, wewemamg dan tugasnya. ${ }^{19}$

Peningkatan kualitas sekolah, kepala sekolah sebagai manajer yang bertanggung jawab terhadap maju mundurnya satuan pendidikan yang menjadi wilayah kekuasaannya dalam memimpin. Dengan demikian yang dilakukan pertama adalah merumuskan visi kepemimpinannya, mempersiapkan sekolah yang layak untuk penyelenggaraan pendidikan dan pembelajaran, bersikap

\footnotetext{
${ }^{17}$ Afiful Ikhwan, "Sistem Kepemimpinan Islami: Instrumen Inti Pengambil Keputusan pada Lembaga Pendidikan Islam,” Istawa: Jurnal Pendidikan Islam 3, no. 2 (2019): 142.

${ }^{18}$ Abdurrahman Abdurrahman dan Azizah Firdausi, "Peran Kepemimpinan Kepala Madrasah Dalam Pengendalian Mutu (Studi Kasus di MTs. Az-Zainiyah 1 Paiton, Probolinggo)," al-fikrah: Jurnal Manajemen Pendidikan 7, no. 1 (2019): 2.

${ }^{19}$ Muh Fitrah, "Peran Kepala Sekolah dalam Meningkatkan Mutu Pendidikan," Jurnal Penjaminan Mutu 3, no. 1 (2017): 32.
} 
sebagai seorang leader di hadapan seluruh staf akademik dan non-akademik, dan mengoptimalkan layanan seluruh stafnya untuk mempercepat kemajuan. ${ }^{20}$

Selain itu, kepala sekolah juga harus terus melakukan analisis terus menerus terhadap kesesuaian hasil belajar siswa dengan visi dan tujuan sekolah, kebutuhan siswa, kebutuhan studi lanjut, sertamengarahkan guru untuk menyesuaikanprogram pembelajaran dan prosespembelajaran dengan pencapaian visi tersebut,serta dengan berbagai variabel kebutuhan siswauntuk studi lanjut dan bahkan untuk mampumenyesuaikan diri dengan kehdupan sosialkemasyarakatan serta berbagai perubahan yangterjadai sangat cepat dalam kehidupan sosial.

Peningkatkan kompetensi para guru kepala sekolah harus memiliki program. Pertama, supervisi pendidikan merupakan pembinaan untuk para guru yang direncanakan guna melakukan pekerjaan secara aktif. Kedua, pendidikan dan pelatihan bertujuan untuk mengembangkan kualitas sumber daya manusia. Ketiga, pemberian motivasi secara continue untuk mendorong para guru mendapatkan hasil yang maksimal. Keempat, perubahan budaya kerja untuk mencipatkan variasi dan perubahan dalam pekerjaan.

Pelaksanaan kepala sekolah juga melibatkan tenaga administrasi sekolah dalam hal ini menempati peranpenting sebagai tenaga kependidikan dengan tugasnya yang bukanhanya sekedar membantu sekolah dalam urusan administrasimelainkan meliputi beberapa kegiatan penting dalam pengembangankualitas sekolah seperti pemahaman sistem kepemimpinan, databasedan prosedur pengambilan keputusan, pengelolaan, pelayanan, pengembangan danpengawasan teknis serta mengembangkan perencananadministrasi sekolah. Dengan kata lain, Tenaga Administrasi Sekolahini bertugas sebagai pendukung berjalannya proses pendidikan disekolah melalui layanan administrasi guna terselenggaranya prosespendidikan yang efektif dan efisien di sekolah. ${ }^{21}$ Kepala sekolah merupakan penanggung-jawab kegiatan administrasi ketatausahaan sekolah dalam mendukung pelaksanaan kegiatan pembelajaran. ${ }^{22}$

Adapun implementasi dari hasil penelitian terkait peran kepemimpinan yang dijalankan kepala madrasah dalam meningkatkan mutu pendidikan di MTs. Swasta Miftahul Falah Diski yaitu (a) Sebagai edukator yang memiliki kemampuan untuk membimbing guru, karyawan, siswa dan staf. (b) Sebagai manager yang memliki kemampuan untuk menyusun program, menyusun organisasi personalia, menggerakkan masing-masing kinerja sumber daya madrasah. (c) Sebagai administator, mengelola administrasi kegiatan belajar mengajar dan bimbingan konseling serta mengelola administrasi kesiswaan, ketenagaan dan keuangan. (d) Sebagai supervisor yang menyusun program supervisi, melaksanakan program supervisi dan menggunakan hasil supervisi.

\footnotetext{
${ }^{20}$ Fitrah, 40.

${ }^{21}$ Afiful Ikhwan, "Sistem Kepemimpinan Islami: Instrumen Inti Pengambil Keputusan pada Lembaga Pendidikan Islam,” Istawa: Jurnal Pendidikan Islam 3, no. 2 (2019): 111.

${ }^{22}$ Baharun, "Peningkatan kompetensi guru melalui sistem kepemimpinan kepala madrasah," 8.
} 
(e) Sebagai leader yang memliki kepribadian yang kuat, memahami kondisi anak buah dengan baik, memliki visi dan memahamai visi sekolah, mampu mengambil keputusan dan berkomunikasi. (f) Sebagai inovator yang mampu mencari/menemukan gagasan baru untuk pembaharuan sekolah. (g) Sebagai motivator yang mampu mengatur lingkungan kerja baik yang fisik maupun non fisik, serta mampu menerapkan prinsip penghargaan dan hukuman. ${ }^{23}$

Selanjutnya hasil penelitian terkait implementasi supervise kepala sekolah terhadap kinerja guru dengan melakukan perencanaan, dengan menyusun program-program supervisi selama satu semester. Adapun hasil penelitian menunjukkan bahwa implementasi supervisi yang dilakukan oleh Kepala Sekolah MIN Kota Bogor, antara lain: memberikan motivasi kepada para guru sebagai ujung tombak keberhasilan dalam mendidik murid, melakukan kegiatan kunjungan ke kelas, berupa kegiatan observasi yang sesekali dilakukan. Program selanjutnya dalam kegiatan supervisi kepala sekolah adalah setelah melakukan supervisi di kelas, dan didapati berberapa permasalahan yang perlu disampaikan, maka setelah itu ditindaklanjuti dengan pembicaraan individual antara kepala sekolah dan guru. Kegiatan selanjutnya adalah melakukan evaluasi dari program supervisi yang dilakukan oleh kepala sekolah dan dibantu oleh wakil kepala sekolah bidang kurikulum menjelang berakhirnya kegiatan semesteran. ${ }^{24}$

\section{KESIMPULAN DAN SARAN}

Simpulan diatas bahwa begitu pentingnya peran kemimpinan kepala sekolah/madrasah dalam meningkatkan mutu pendidikan Islam. Setiap pekerjaan dalam lembaga pendidikan kunci keberhasilan terletak pada kepemimpinan. Maka sebagai seorang pemimpin dituntut mampu mengemban tugas dan tanggung jawab sebagai sosok panutan bagi anggota atau bawahan untuk menciptakan inovasi, meningkatkan kualitas dan mengembangkan performa mutu lembaga pendidikan Islam sehingga memperoleh hasil yang sesuai dengan harapan yang diinginkan. Adapun peran kepemimpinan dalam menjalankan tugasnya kepada anggota meliputi: (a) Mengambil keputusan. (b) Mengembangkan imajinasi; (c) Mengembangkan kesetiaan pengikutnya; (d) Pengendalian rencana; (e) Memanfaatkan sumber daya manusia dan sumber-sumber lainnya. (f) Melaksanakan kontrol dan perbaikan-perbaikan atas kesalahan; (g) Memberikan tanda penghargaan; (h) Mendelegasikan wewenang kepada bawahannya; (i) Pelaksanaan keputusan dengan memberikan dorongan kepada para pengikutnya.

\footnotetext{
${ }^{23}$ Ahmad Ibrahim Hasibuan, Mustapid Mustapid, dan Candra Wijaya, "Peran Kepemimpinan Kepala Madrasah dalam Meningkatkan Mutu Pendidikan di MTs. Swasta Miftahul Falah Sunggal Kabupaten Deli Serdang," Anthropos: Jurnal Antropologi Sosial dan Budaya (Journal of Social and Cultural Anthropology) 4, no. 2 (2019): 209-210.

${ }^{24}$ Sarifudin Sarifudin, "Implementasi Supervisi Kepala Sekolah Terhadap Kinerja Guru Dalam Upaya Meningkatkan Kualitas Pembelajaran Di Madrasah Ibtidaiyah Negeri (Min) Kota Bogor," Islamic Management: Jurnal Manajemen Pendidikan Islam 2, no. 01 (2019): 49.
} 
Adapun saran penelitian ini adalah untuk meningkatkan kepemimpinan mutu pendidikan islam khususnya di Madrasah melalui penelitian lebih lanjut guna memperoleh kualitas lembaga pendidikan islam yang bermutu.

\section{DAFTAR RUJUKAN}

Abdurrahman, dan Azizah Firdausi. "Peran Kepemimpinan Kepala Madrasah Dalam Pengendalian Mutu (Studi Kasus di MTs. Az-Zainiyah 1 Paiton, Probolinggo)." alfikrah: Jurnal Manajemen Pendidikan 7, no. 1 (2019): 1-10.

Baharun, Hasan. "Peningkatan kompetensi guru melalui sistem kepemimpinan kepala madrasah.” At-Tajdid: Jurnal Ilmu Tarbiyah 6, no. 1 (2018): 1-26.

Crawford, Megan. (20050.Leadership and teams in educational management, Terj. Erick Dibyo, Jakarta: grasind.

Fitrah, Muh. "Peran kepala sekolah dalam meningkatkan mutu pendidikan." Jurnal Penjaminan Mutu 3, no. 1 (2017): 31-42.

Hasibuan, Ahmad Ibrahim, Mustapid Mustapid, dan Candra Wijaya. "Peran Kepemimpinan Kepala Madrasah dalam Meningkatkan Mutu Pendidikan di MTs. Swasta Miftahul Falah Sunggal Kabupaten Deli Serdang." Anthropos: Jurnal Antropologi Sosial dan Budaya (Journal of Social and Cultural Anthropology) 4, no. 2 (2019): 201-210.

Ikhwan, Afiful. "Sistem Kepemimpinan Islami: Instrumen Inti Pengambil Keputusan pada Lembaga Pendidikan Islam.” Istawa: Jurnal Pendidikan Islam 3, no. 2 (2019): $111-154$.

Muhaimin, (2011). Manajemen Pendidikan: Aplikasinya dalam Penyusunan Rencana Pengembangan Sekolah/Madrasah,Jakarta: Kencana.

Mulyadi, (2010).Kepemimpinan Kepala Sekolah Mengembangkan Budaya Mutu, Malang: UIN-Maliki Press.

Sallis, Edward. (2012).Total Quality Management in Education, Yogyakarta: IRCiSoD/

Salminawati, (2016). Filsafat Pendidikan Islam,Bandung, Media Perintis.

Sarifudin. "Implementasi Supervisi Kepala Sekolah Terhadap Kinerja Guru Dalam Upaya Meningkatkan Kualitas Pembelajaran Di Madrasah Ibtidaiyah Negeri (Min) Kota Bogor." Islamic Management: Jurnal Manajemen Pendidikan Islam 2, no. 01 (2019): 49-70. 